\title{
Estudio de la cinética del fraguado de cementos P-350 por resonancia magnética nuclear
}

\author{
Study of P-350 cement setting kinetic \\ by nuclear magnetic resonance
}

\author{
GABRIEL L. DUQUE FERNÁNDEZ \\ Laboratorio Central del Cemento del MIMC \\ DAVID DÍAZ QUINTANILLA, ROGELIO CAPOTE RODRÍGUEZ, MANUEL ZAPATA SIERRA \\ CEADEN, P. O. Box 6122, La Habana
}

Fecha de recepción: 18-VI-93.

CUBA

\section{$R E S U M E N$}

En el presente trabajo se presenta el estudio de la cinética del proceso de fraguado del cemento empleando un método novedoso que permite investigar microscópicamente la evolución de la hidratación del cemento, el cual fue aplicado al estudio de tres cementos cubanos $P$-350. Se obtuvieron los valores iniciales y finales de las superficies específicas de los productos de hidratación y del cemento. Se caracterizaron los diferentes períodos del proceso de hidratación de las pastas de cemento. Se muestra la influencia de la composición fásica del cemento sobre el desarrollo superficial de la pasta hidratada.

\begin{abstract}
$S U M M A R Y$
A kinetic study of cement setting process is presented in this paper. A new method which allows the microscopic research of the evolution of the cement hydration applied to the study of three P-350 cuban cements is used. The initial and final values of the specific surfaces of the hydration products and cement were obtained, and the different periods of the hydration process of cement pastes were characterized. The influence of the cement phase composition on the surface development of the hydrated cement stone is discussed.
\end{abstract}

\section{INTRODUCCIÓN}

El estudio de la cinética de los procesos de fraguado y endurecimiento del cemento presenta una enorme importancia, tanto desde el punto de vista práctico, como teórico, ya que permite conocer los factores que influyen de una $u$ otra forma sobre los parámetros que los caracterizan, proporcionando criterios adecuados para la determinación de los aditivos que deben añadirse al clínker con el objetivo de obtener una pasta endurecida con las mejores características físicas, de acuerdo con el uso que se le vaya a dar al cemento $(1,2)$.

Se han usado varios métodos generales en el estudio de la cinética de la hidratación del cemento (2), entre los cuales han jugado un papel

\section{INTRODUCTION}

A kinetic study of setting and hardening processes of cement are of great importance both since the practical and the theoretical point of view as it allows to know the factors influencing, in one way or another, the parameters which characterize them, thus giving adequate criteria to determine the additives that must be added to the clinker to obtain a solid phase with the physical characteristics required for cement uses $(1,2)$.

Several general methods have been used in the study of cement hydration kinetic (2). Some of the most remarkable ones are the microscopic 
muy importante el examen microscópico de pastas puras de cemento endurecidas después de tiempos de curado conocidos, observaciones de los cambios en las propiedades químicas y físicas de las pastas en función del tiempo de curado, el análisis por difracción de rayos $X$ de las partículas de clínker no hidratadas en las pastas endurecidas, y últimamente la espectroscopía de RMN de $\mathrm{Si}^{29}$ en estado sólido (3-5) y la relajación magnética nuclear protónica en las pastas de cemento durante su endurecimiento $(6,7)$. Este último método, a diferencia de los anteriores, permite realizar las mediciones de manera continua, sin influir en el proceso de fraguado y endurecimiento.

En $(6,7)$ se presenta un estudio del proceso de fraguado y endurecimiento del cemento y la influencia de adiciones sobre dicho proceso. En estos trabajos se demuestra la relación existente entre el tiempo de relajación espín-retículo $T_{1}$ y el desarrollo superficial del cemento durante el tiempo de hidratación. Estas dependencias tienen una forma característica con tres regiones perfectamente diferenciables, las cuales reflejan diferentes estadios del proceso.

Con el objetivo de aplicar el método de RMN al estudio del cemento cubano, se estableció una correlación entre el desarrollo superficial y el tiempo de fraguado para diferentes muestras de cemento P-350 de las fábricas "José Mercerón" de Santiago de Cuba, "26 de Julio" de Nuevitas y "Carlos Marx" de Cienfuegos.

\section{TEORÍA}

\section{Monitoreo del desarrollo superficial en las pastas de cemento}

La superficie de la materia sólida en contacto con agua en la pasta puede ser expresada como (6):

$$
S_{R M N}=\frac{1}{\alpha} s_{1} N_{b}
$$

donde $N_{b}$ es el número de moléculas de agua adsorbidas. $\mathrm{S}_{1}$ el área promedio sobre la superficie sólida ocupada por una sola molécula adsorbida y $\alpha$ el número de capas monomoleculares en la fase adsorbida que se relajan con un tiempo de relajación efectivo $T_{1 b}$.

La superficie $S_{1}$ ha sido extensamente estudiada

(8) y se ha reportado un valor de $11,4 \times 10^{-2} \mathrm{~nm}^{2}$.

La superficie específica por gramo de cemento $\mathrm{S}_{\mathrm{RMN}}$ se puede expresar como: examination of pure cement slurries hardened after known hydration times, observations of the changes in the chemical and physical properties of the slurries, $X$-Ray diffraction of non-hydrated clinker particles in cement stone and lately $S i^{29}$ solid state NMR (3-5) and proton nuclear magnetic relaxation method in hydrated cement during their hardening $(6,7)$. The last method, unlike the others, allows continuous measurements without affecting setting and hardening processes.

Studies of cement setting and hardening and the influence of additions upon that process by the proton nuclear magnetic relaxation method are presented in $(6,7)$. Those works show that the dependence of the spin-lattice relaxation time $T_{\text {, }}$ on the hardening (hydration) time has a characteristic form with three perfectly differentiated regions, each one related to a different stage of the process.

A correlation between surface development and the setting time for different P-350 cement samples from the factories of "Jose Merceron" in Santiago de Cuba, "26 de Julio" in Nuevitas and "Carlos Marx" in Cienfuegos, was established so as to apply the NMR method to the study of cuban cements.

\section{THEORY}

\section{Surface development monitoring in cement slurries}

The surface of the solid matter in contact with water in the slurry (6) can be expressed as:

$$
S_{N M R}=\frac{1}{\alpha} s_{1} N_{b}
$$

where $N_{b}$ is the number of adsorbed water molecules, $S_{1}$ is the average area on the solid surface occupied by a single adsorbed water molecule and $\alpha$ is the number of monomolecular layers in the adsorbed phase which are relaxed with the effective proton relaxation time $T_{1 b}$.

$S_{i}$ surface has been extensively studied (8) and a $11.4 \times 10^{-2} \mathrm{~nm}^{2}$ value was reported.

The specific surface per gram of cement $S_{N M R}$ can be expressed as: 


$$
S_{\text {RMN }}=\frac{S_{\text {RMN }}}{m_{c}}=\frac{A}{\alpha}\left(\frac{T_{1 b}}{T_{1 e f f}}\right) /\left(\frac{1}{(\omega / c)}\right)
$$

donde $\mathrm{A}$ es una constante que representa el área de la superficie cubierta por una capa monomolecular compacta de un gramo de agua, $\mathrm{w} / \mathrm{c}=\mathrm{m}_{\mathrm{w}} / \mathrm{m}_{\mathrm{c}}$ y $\mathrm{m}_{\mathrm{c}}$ es la masa de cemento al principio del proceso de hidratación.

Desde el punto de vista de la RMN, el desarrollo superficial en la hidratación de pastas de cemento se trata de forma análoga a lo descrito

anteriormente, sólo que los parámetros $T_{1 \text { fefe, }} T_{1 b} y$ $\mathrm{N}_{\mathrm{b}}$ son funciones del tiempo de hidratación, así la superficie $S_{\text {RMN }}(t)$ se expresa como:

$$
S_{\text {RMN }}(t)=\frac{S_{i}}{\alpha} N(t) \frac{T_{1 b}(t)}{T_{1 \text { 1eefec }}(t)}
$$

Debido a que el agua reacciona con el cemento, la masas de agua intercambiable $m_{w}$ (1) decrece con el tiempo de hidratación. Esta masa puede ser monitoreada por RMN directamente ya que la señal de RMN es proporcional al número relativo de protones del agua. Así la masa $m_{w}(1)$ puede ser comparada con su valor inicial $m_{w}$ a través de las mediciones de las correspondientes áreas de los espectros de RMN I (t) e I respectivamente. Por tanto:

$$
m_{w}(t)=m_{w} \frac{I(t)}{l}
$$

De la misma forma, el número de moléculas de agua intercambiables en la pasta que se está endureciendo puede ser obtenido directamente a través de la ecuación:

$$
N(t)=N \frac{I(t)}{l}
$$

Luego de algunas transformaciones se obtiene para $S_{\mathrm{RMN}}(\mathrm{t})$ la siguiente relación:

$$
S_{\text {RMN }}(t)=S_{\text {RMN }} \frac{I(t)}{l} \frac{T_{1 b}(t)}{T_{1 b}} \frac{T_{1 \text { efoc }}}{T_{1 \text { efoc }}(t)}
$$

El agua intercambiable en la pasta puede utilizarse como sonda, ya que ella forma una "réplica" de los productos de hidratación y tiene su propia superficie específica, la cual se denota como $Z_{\text {RMN }}(t)$ y se define como:

$$
S_{\text {RMN }}=\frac{S_{\text {RMN }}}{m_{c}}=\frac{A}{\alpha}\left(\frac{T_{1 b}}{T_{1 e f f}}\right) /\left(\frac{1}{(\omega / c)}\right)
$$

where $A$ is the constant representing the surface area covered by a compact monomolecular layer made of 1 gram of water, $w / c=m_{w} / m_{c}$ and $m_{c}$ is the cement mass at the beginning of the hydration process.

The study of the surface development in the hydration of cement slurries by NMR is treated in the same way as described above, but $T_{1 \text { eff }}, T_{1 b}$ and $N_{b}$ are functions of the hydration time and the $S_{N M R}(t)$ surface is expressed as:

$$
S_{N M R}(t)=\frac{S_{i}}{\alpha} N(t) \frac{T_{1 b}(t)}{T_{1 e e f e c}(t)}
$$

Due to the fact that water reacts with cement, the exchangeable water mass $m_{w}(1)$ decreases with the hydration time. This mass can be monitored by NMR directly because the NMR signal is proportional to the relative number of water protons. Therefore, the $m_{w}$ (1) mass can be compared to the $m_{w}$ initial value by measuring the corresponding areas of the NMR spectra I ( $t$ ) and I respectively, thus:

$$
m_{w}(t)=m_{w} \frac{I(t)}{l}
$$

In the same way the $N(t)$ number of exchangeable water molecules in the hardening paste can be directly expressed as:

$$
N(t)=N \frac{I(t)}{l}
$$

After some operations the following relation is obtained for $S_{N M R}(t)$.

$$
S_{N M R}(t)=S_{N M R} \frac{l(t)}{l} \frac{T_{1 b}(t)}{T_{1 b}} \frac{T_{1 \text { efec }}}{T_{\text {1efec }}(t)}
$$

The exchangeable water in the slurry can be used as a measuring medium, because it forms a "replica" of the hydration products and has its own specific surface, which is denoted as $Z_{\text {NMR }}(t)$ and defined as: 


$$
Z_{\text {RMN }}(t)=\frac{S_{\text {RMN }}(t)}{m_{w}(t)}=\frac{S_{R M N}}{(w / c)} \frac{T_{1 b}(t)}{T_{1 b}} \frac{T_{1 e f e c}}{T_{1 \text { efec }}(t)}
$$

Con la ayuda de esta fórmula se puede seguir la cinética de fraguado y desarrollo superficial del cemento.

\section{MATERIALES Y MÉTODOS}

Para cada fábrica se preparó un mortero (mezcla de agua destilada y cemento en ámpula de vidrio), con relación agua cemento (w/c) de 0,5.

\section{$C_{1}$ : muestra $1 / 89$ de la "José Mercerón" de Santiago de Cuba,}

$\mathrm{C}_{2}$ : muestra 74/89 de la "Carlos Marx" de Cienfuegos, y

$\mathrm{C}_{3}$ : muestra $34 / 90$ de la "26 de Julio" de Nuevitas,

para un total de tres muestras, a las cuales se le realizaron los estudios físico-químicos de rutina, presentados en las tablas 1,2 y 3 .

Las pastas se prepararon por pesada, directamente en el interior de las ámpulas de vidrio que se utilizaron para la medición y ocuparon un volumen de aproximadamente $1 \mathrm{~cm}^{3}$. Posteriormente, las ámpulas fueron selladas.

Las mediciones se realizaron en un espectrómetro de RMN de pulsos BRUKER CXP-90. El tiempo de relajación espín-retículo $T_{1}$ fue determinado por el método de los dos puntos, el cual consiste en aplicar secuencias de pulso $180^{\circ}-\tau-90^{\circ}$, variando el tiempo $\tau$ con el objetivo de encontrar para qué valor $\tau_{\mathrm{p}}$ se obtiene una magnetización cercana a cero. Luego $T_{1}$ se determina como:

$$
T_{1}=\frac{\tau_{p}}{\ln 2}
$$

Este método introduce un $5 \%$ de error.

El área de la señal de RMN se calculó a partir de espectros obtenidos con 200 acumulaciones, lo cual garantizó una buena relación señal/ruido, por lo que el error de esta medición fue menor que $5 \%$.

Tanto en las mediciones de $T_{1}$ como del área, la señal de RMN se obtuvo a partir de los $40 \mu \mathrm{s}$ luego de aplicado el pulso de $\pi / 2$, siguiendo la metodología propuesta en (6).

$$
Z_{N M R}(t)=\frac{S_{N M R}(t)}{m_{w}(t)}=\frac{S_{N M R}}{(w / c)} \frac{T_{1 b}(t)}{T_{1 b}} \frac{T_{1 e f e c}}{T_{1 e f e c}(t)}
$$

With the aid of this formula the kinetic of the surface development and setting of cement could be followed.

\section{EXPERIMENTAL PROCEDURE}

A mortar (a mixture of distilled water and cement in a glass bulb) were prepared for each factory with a water/cement ratio $(w / c)$ of 0.5 :

$$
\begin{aligned}
& C_{1}: \begin{array}{l}
\text { sample } 1 / 89 \text { from "Jose Merceron" in } \\
\text { Santiago de Cuba, }
\end{array} \\
& C_{2}: \begin{array}{l}
\text { sample } 74 / 89 \text { from "Carlos Marx" in } \\
\text { Cienfuegos and }
\end{array} \\
& C_{3}: \text { sample } 34 / 90 \text { from "26 de Julio" in } \\
& \text { Nuevitas, }
\end{aligned}
$$

for a total of three samples to which routine physical and chemical studies shown in tables 1, 2 and 3 were made.

The slurries were prepared by weighing directly within the glass bulb used for measurement. Later they were sealed. The approximate volume occupied was $1 \mathrm{~cm}^{3}$.

The measurements were made in a BRUKER CXP-90 NMR pulse spectrometer. The spin lattice relaxation time $T_{\text {, was determined by the two- }}$ points method. It consists on the application of $180^{\circ}-\tau-90^{\circ}$, pulse sequences changing the $\tau$ time so as to find the $\tau_{p}$ value which corresponds to a magnetization close to zero. Later on, $T_{1}$ is determined as:

$$
T_{1}=\frac{\tau_{p}}{\ln 2}
$$

This method introduces an error of $5 \%$.

The NMR signal area was calculated using spectra measured with 200 scans, thus a good signal-to-noise ratio and therefore an error less than $5 \%$ was obtained.

For the measurements of $T_{1}$ as well as the area the NMR signal was obtained since $40 \mu \mathrm{seg}$ after the $T_{i} / 2$ pulse was applied, using the methodology reported in (6). 
TABLA 1 TABLE 1

Caracterización física (Phisical characterization)

\begin{tabular}{|c|c|c|c|c|c|c|}
\hline $\begin{array}{l}\text { Muestra } \\
\text { [Sample] }\end{array}$ & $\begin{array}{l}\text { Finura } \\
(\%) \\
\text { [Fines } \\
(\%)]\end{array}$ & $\begin{array}{c}\text { F.I. } \\
\text { (min.) } \\
{[\text { F.I. }} \\
\text { (min.)] }\end{array}$ & $\begin{array}{c}\text { F.F. } \\
\text { (horas) } \\
\text { F.F. } \\
\text { (hours)] }\end{array}$ & $\begin{array}{l}\text { Expansión } \\
(\mathrm{mm}) \\
\text { [Expansion } \\
(\mathrm{mm})]\end{array}$ & $\begin{array}{l}\text { SEB } \\
\left(\mathrm{m}^{2} / \mathrm{g}\right) \\
{[\mathrm{BSS}} \\
\left.\left(\mathrm{m}^{2} / \mathrm{g}\right)\right]\end{array}$ & $\begin{array}{l}\text { P. específico } \\
\left(\mathrm{g} / \mathrm{cm}^{3}\right) \\
{\left[\begin{array}{c}\text { [Especific w. } \\
\left.\left(\mathrm{g} / \mathrm{cm}^{3}\right)\right]\end{array}\right.}\end{array}$ \\
\hline $\mathrm{C}_{1}$ & 84 & 130 & 3,05 & 0,8 & 0,3111 & 3,20 \\
\hline $\mathrm{C}_{2}$ & 97,6 & 155 & 4,05 & 0,6 & 0,3556 & 3,24 \\
\hline $\mathrm{C}_{3}$ & 91,3 & 95 & 3,10 & 1,20 & 0,3105 & 3,19 \\
\hline
\end{tabular}

TABLA 2 TABLE 2

Composición química (Chemical composition)

\begin{tabular}{|c|c|c|c|}
\hline \multirow{2}{*}{$\begin{array}{c}\text { Composición } \\
\text { (Composition) }\end{array}$} & \multicolumn{3}{|c|}{$\%$ en peso ( $\%$ in weight) } \\
\hline & $C_{1}$ & $\mathrm{C}_{2}$ & $\mathrm{C}_{3}$ \\
\hline Cal libre (free lime) & 1,50 & 0,72 & 1,43 \\
\hline $\mathrm{SiO}_{2}$ & 20,52 & 20,48 & 20,43 \\
\hline $\mathrm{Al}_{2} \mathrm{O}_{3}$ & 5,40 & 4,05 & 5,48 \\
\hline $\mathrm{Fe}_{2} \mathrm{O}_{3}$ & 4,69 & 5,18 & 3,96 \\
\hline $\mathrm{CaO}$ & 62,15 & 63,92 & 61,46 \\
\hline $\mathrm{MgO}$ & 1,40 & 1,55 & 1,80 \\
\hline $\mathrm{Na}_{2} \mathrm{O}$ & 0,78 & 0,25 & 0,62 \\
\hline $\mathrm{K}_{2} \mathrm{O}$ & 0,39 & 0,34 & 0,59 \\
\hline $\mathrm{SO}_{3}$ & 1,99 & 1,83 & 2,59 \\
\hline P.F. & 1,14 & 0,88 & 1,88 \\
\hline R.I. & 0,97 & 1,03 & 0,61 \\
\hline
\end{tabular}

TABLA 3 TABLE 3

Composición fásica (Phase composition)

\begin{tabular}{|c|c|c|c|c|}
\hline Muestra (Sample) & $\mathbf{C}_{3} \mathbf{S}$ & $\mathbf{C}_{2} \mathbf{S}$ & $\mathbf{C}_{3} \mathbf{A}$ & $\mathbf{C}_{4} \mathbf{A F}$ \\
\hline$C_{1}$ & 42,29 & 22,93 & 6,37 & 14,27 \\
\hline$C_{2}$ & 58,00 & 16,39 & 1,97 & 15,76 \\
\hline$C_{3}$ & 39,20 & 29,00 & 7,82 & 12,05 \\
\hline
\end{tabular}


Todas las mediciones se realizaron a la temperatura ambiente.

\section{RESULTADOS Y DISCUSIÓN}

La dependencia de $T_{\text {1efec }}$ del tiempo de hidratación para los tres cementos estudiados son mostradas en la Fig. 1. Por razones experimentales no pudieron realizarse las mediciones correspondientes al intervalo de tiempo de las 24 horas a las 45 horas.

En las primeras tres horas del proceso de hidratación se observa un período latente en el que las funciones de relajación protónica son exponenciales simples, como es característico para el intercambio rápido entre las moléculas en la fase adsorbida y la fase libre (Bulk). Después de este período se hizo más significativa una desviación del comportamiento exponencial simple hasta aproximadamente las 15 horas, donde se comienza a observar un comportamiento multiexponencial, el cual refleja el llamado "fraguado ficticio" hasta las 40 horas. Este efecto ha sido observado en otros trabajos (6 y las referencias en él), pero aún no existe una explicación satisfactoria para el mismo.

Alrededor de las 150 horas se alcanza una "meseta" para los valores de $T_{1 \text { fef }}$ de 1,6 m, $0,9 \mathrm{~m}$ y $2,1 \mathrm{~m}$, para las muestras $\mathrm{C}_{1}, \mathrm{C}_{2}$ y $\mathrm{C}_{3}$ respectivamente.

En la Fig. 2 se presenta la variación del área de la señal de RMN durante el proceso de fraguado de los cementos $C_{1}, C_{2}$ y $C_{3}$. Este área disminuye gradualmente con el incremento del tiempo de hidratación, debido a que el agua intercambiable se incorpora constantemente a la estructura de los nuevos productos de hidratación formados, por lo que, como se explicaba anteriormente, desaparece del domicilio de observación. La diferencia entre las áreas de los tres cementos $\left(C_{2}>C_{1}>C_{3}>\right)$ se debe a que los mismos tenían diferentes grados de humedad inicial, provocado entre otras cosas por las diferentes superficies específicas de Blaine SEB $\left(\mathrm{C}_{2}>\mathrm{C}_{1}>\mathrm{C}_{3}>\right)$

En las Figs. 3 y 4 aparecen las dependencias de las superficies especiicas $S_{R M N}(t)$ y $Z_{R M N}(t)$ para las muestras antes citadas.

Los valores numéricos de $S_{\text {RMN }}(t)$ y $Z_{\text {RMN }}(t)$ son calculados asumiendo que el $\mathrm{T}_{1 \mathrm{~b}}$ de las moléculas de agua en la fase adsorbida tiene un valor constante durante el proceso de hidratación, lo cual es una buena aproximación para cementos puros. El valor de $T_{1 \text { efec }}$ para pastas frescas
All measurements were made at room temperature.

\section{RESULTS AND DISCUSSION}

The dependence of $T_{\text {teff }}$ on the hydration time for the three cements studied are shown in figure 1. Due to experimental reasons, the measurements corresponding to the time interval from 24 to 45 hours could not be carried out.

During the three hours of the hydration process, Fig. 1 shows a dormat period when the proton relaxation functions are simple exponentials as it is characteristic of the rapid exchange among molecules in the adsorbed phase and in the free phase (Bulk). After this period a deviation from the simple exponential behaviour became more significant up to approximately 15 hours when a multiexponential behaviour was observed, reflecting the so-called "fictitious setting" up to the $40^{\text {th }}$ hour. This effect had been noted in other works (6 and references in it), but there is still no satisfactory explanation for it.

After 150 hours a plateau is reached for the $T_{1 \text { eff }}$ values $1.6 \mathrm{~ms}, 0.9 \mathrm{~ms}$ and $2.1 \mathrm{~ms}$ for $C_{1}, C_{2}$ and $C_{3}$ samples respectively.

Figure 2 shows the variation of the NMR signal area during the cement setting process of $C_{1}, C_{2}$ and $C_{3}$. This area decreases slowly as the hydration time increases because the exchangeable water is continuously entering the structure of newly formed hydration products and is thus disappearing from the observation domain. The difference among the areas of the three cements $\left(C_{2}>C_{1}>C_{3}>\right)$ is caused by the fact that they had different initial humidity degrees due to their different Blaine Specific Surfaces BSS $\left(C_{2}>C_{1}>C_{3}>\right.$ ).

Figures 3 and 4 show the dependence of the specific surfaces of $S_{N M R}(t)$ and $Z_{N M R}(t)$ on time for the samples above mentioned.

Numerical values of $S_{N M R}(t)$ and $Z_{N M R}(t)$ are calculated assuming that $T_{1 b}$ of the water molecules in the adsorbed phase has a constant value during the hidration process. This seems to be a good approximation for pure cements. The value of $T_{\text {teff }}$ for fresh slurries dried to $373 k$ was 


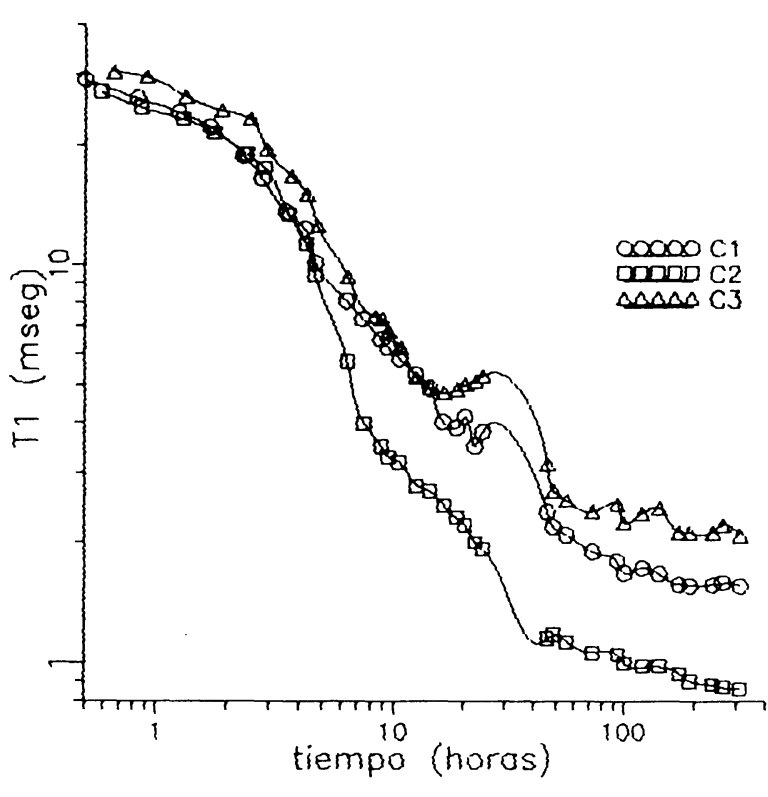

Fig. 1.-Dependencia temporal del tiempo de relajación.

Fig. 1.-Temporal dependence of relaxation time.

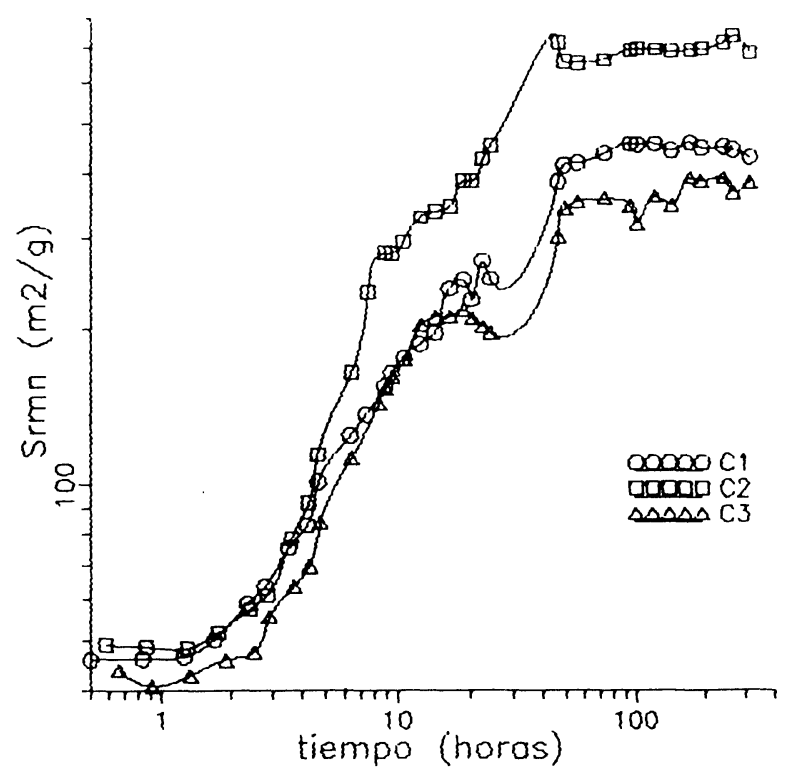

Fig. 3.-Dependencia temporal de la superficie especifica por gramo de cemento.

Fig. 3.-Temporal dependence of specific surface per gram of cement.

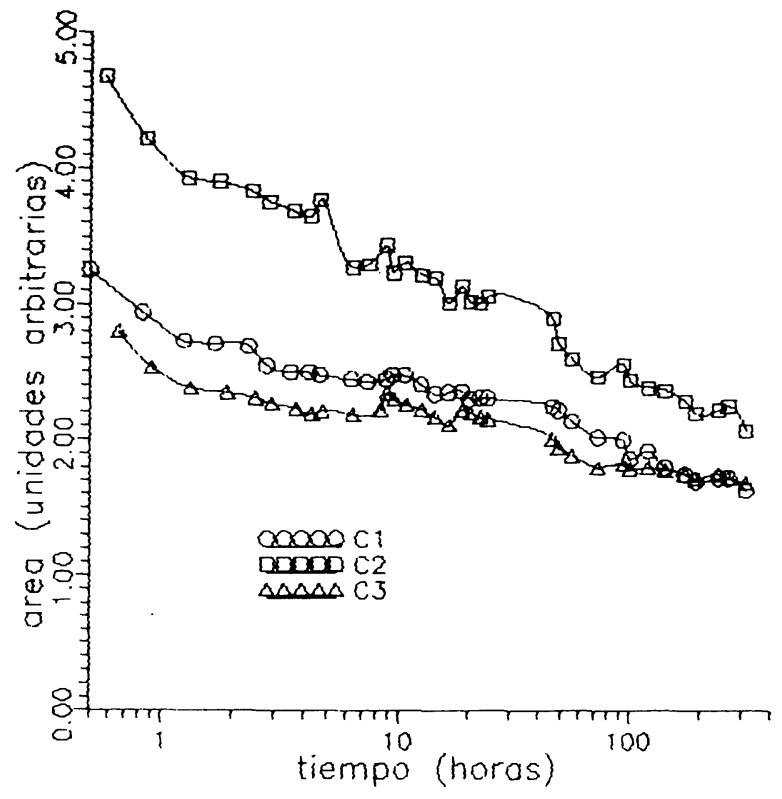

Fig. 2.-Dependencia temporal de la cantidad de agua no cristalina.

Fig. 2.-Temporal dependence of non-crystalline water amount.

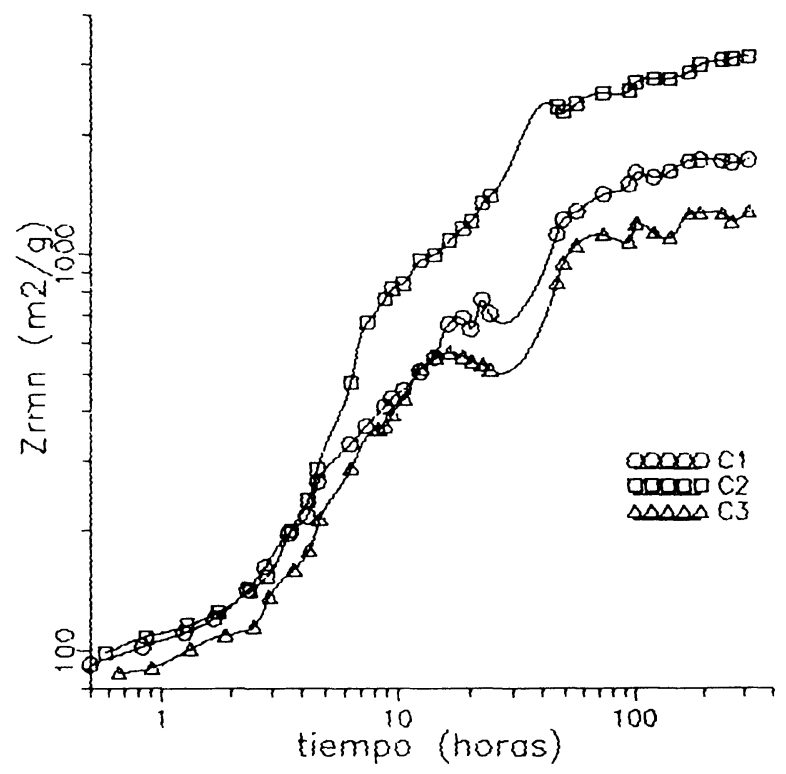

Fig. 4.-Dependencia temporal de la superficie específica de los productos de hidratación.

Fig. 4.- Temporal dependence of the hydration products specific surface. 


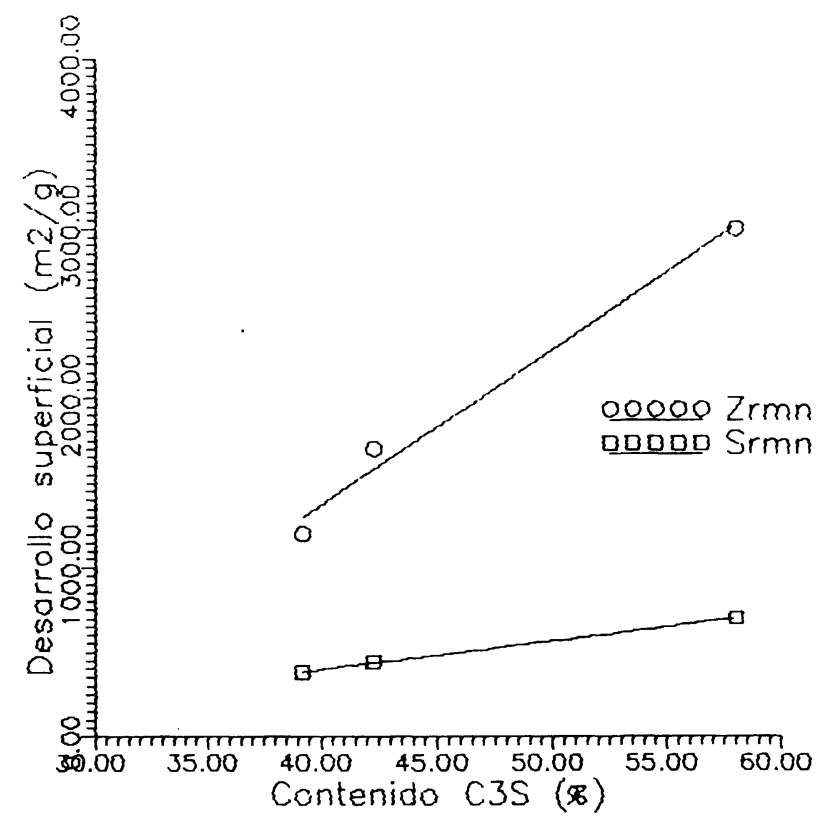

Fig. 5.-Dependencia del desarrollo superficial del contenido de $\mathrm{C}_{3} \mathrm{~S}$.

Fig. 5.-Dependence of surface development on $C_{3} S$ content.

secadas a $373 \mathrm{k}$ fue de $0,7 \mathrm{~m}$. Teniendo en cuenta que este resultado conincide con lo reportado en la literatura (6) puede considerarse que $T_{1 b}=0,7 \mathrm{~m}$.

Las curvas $S_{\text {RMN }}(t)$ en la Fig. 3 muestran que al inicio del proceso de hidratación, el agua intercambiable en la pasta de cemento está en contacto con una superficie relativamente pequeña, cuyos valores iniciales son $46 \mathrm{~m}^{2} / \mathrm{g}$, $49 \mathrm{~m}^{2} / \mathrm{g}$, y $43 \mathrm{~m}^{2} / \mathrm{g}$, para $\mathrm{C}_{1}, \mathrm{C}_{2}$ y $\mathrm{C}_{3}$ respectivamente. Con respecto a los valores finales $(t>70 h)$ se observa que para $C_{1}$ es de $440 \mathrm{~m}^{2} / \mathrm{g}$, para $\mathrm{C}_{2}$ es de $700 \mathrm{~m}^{2} / \mathrm{g}$ y para $\mathrm{C}_{3}$ es de $380 \mathrm{~m}^{2} / \mathrm{g}$. Esta diferencia se debe a que las muestras poseen proporciones de $\mathrm{C}_{3} \mathrm{~S}$ de $\mathrm{C}_{2}>\mathrm{C}_{1}>\mathrm{C}_{3}$, lo cual implica un mayor desarrollo de los hidratos y por lo tanto de la superficie. En la Fig. 5 se observa la buena correlación existente entre el desarrollo superficial y los contenidos de $\mathrm{C}_{3} \mathrm{~S}$.

El comportamiento de la superficie específica $Z_{R M N}(t)$ es similar al de $S_{R M N}(t)$.

Los valores iniciales y finales son: para $\mathrm{C}_{1}, 85 \mathrm{~m}^{2} / \mathrm{g}$ y $1.700 \mathrm{~m}^{2} / \mathrm{g}$; para $\mathrm{C}_{2}, 90 \mathrm{~m}^{2} / \mathrm{g}$ y $3.000 \mathrm{~m}^{2} / \mathrm{g} ;$ y para $\mathrm{C}_{3}, 80 \mathrm{~m}^{2} / \mathrm{g}$ y $1.200 \mathrm{~m}^{2} / \mathrm{g}$. La explicación de estos resultados es la misma que para el comportamiento de $S_{\mathrm{RMN}}(\mathrm{t})$.
$0.7 \mathrm{~ms}$. This result agree with those reported in literature (6), therefore $T_{1 b}=0.7 \mathrm{~ms}$.

$S_{N M R}(t)$ curves in figure 3 show that at the beginning of the hydration process, the exchangeable water in the cement slurry is in contact with a relatively small surface with initial values of: $46 \mathrm{~m}^{2} / \mathrm{g}, 49 \mathrm{~m}^{2} / \mathrm{g}$ and $43 \mathrm{~m}^{2} / \mathrm{g}$ for $\left(C_{1}, C_{2}\right.$ and $C_{3}$ respectively. In reference to the final values $(t>70 \mathrm{~h})$, it is noted that the surface is $440 \mathrm{~m}^{2} / \mathrm{g}$ for $C_{1}, 700 \mathrm{~m}^{2} / \mathrm{g}$ for $C_{2}$ and $380 \mathrm{~m}^{2} / \mathrm{g}$ for $C_{3}$. These differences are due to the fact that the samples have different $C_{3} S$ contents $\left(C_{2}>C_{1}>C_{3}>\right)$, which implies differrent development of hydrates and therefore of the surfaces. Fig. 5 shows the high correlation between the surface development and the $C_{3} S$ contents.

The behaviour of the $Z_{N M R}$ (t) specific surface is similar to that of $S_{N M R}(t)$. The initial and final values are: for $C_{1}, 85 \mathrm{~m}^{2} / \mathrm{g}$ and $1700 \mathrm{~m}^{2} / \mathrm{g}$; for $C_{2}$, $90 \mathrm{~m}^{2} / \mathrm{g}$ and $3300 \mathrm{~m}^{2} / \mathrm{g}$; and for $C_{3} 80 \mathrm{~m}^{2} / \mathrm{g}$ and $1200 \mathrm{~m}^{2} / \mathrm{g}$. The explanation for these results is the same as that for the behaviour of $S_{N M R}(t)$. 


\section{CONCLUSIONES}

Las mediciones de RMN reportadas aquí evidencian las posibilidades de este método en el estudio del proceso de hidratación de las pastas de cemento, así como se demuestra una vez más la influencia de la composición fásica del cemento sobre el desarrollo superficial de la pasta hidratada.

\section{CONCLUSIONS}

The NMR measurements in this work show the possibilities of this method in the study of cement slurries hydration process. The influence of phase composition upon the surface development of the hydration paste is proved once more.

\section{BIBLIOGRAFÍA}

\section{REFERENCES}

(1) Memorias de la Il Escuela para los problemas actuales de las Ciencias Nucleares. La Habana, Julio 29-Agosto 3, 1985, p. 408.

(2) LEA, F. M.: The Chemistry of Cement and Concrete. $3 .^{a}$ edición (Edward Arnold, Londrés, 1970).

(3) LIPPMAA E. y otros: Cem. Conc. Res. v. 12, p. 597, 1982.

(4) PARRY-JONES O. y otros: Cem. Conc. Res. v. 19, p. 228, 1989.

(5) BARNER, J. R. y otros: J. of Mat. Sci. Letters. v. 4, p. 1.293, 1985

(6) BARBIČ, L. y otros: J. Am. Ceram. Soc. v. 65, N. $^{\circ} 1$, p. 25, 1982

(7) BARBIČ, L. y otros: Ciments, Betons, Platres, Chaux. v. 718, N. ${ }^{\circ} 3$, p. $172,1979$.

(8) BRUNAUER, S. y otros: J. Am. Chem. Soc. v. 80, N. ${ }^{\circ} 4$, p. $761,1958$.

\section{publicación del ICCET/CSIC}

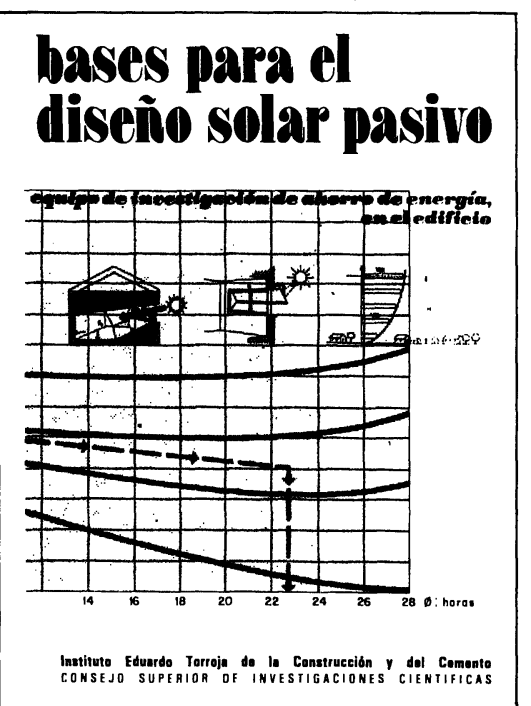

Equipo de Ahorro de Energía en el edificio

Dirección y coordinación:

Arturo Garcia Arroyo

M. a José Escorihuela

José Luis Esteban

José Miguel Frutos

Manuel Olaya

Bernardo Torroja caso y lugar.
Las dificultades de suministro y el alto coste de los productos energéticos convencionales han despertado la atención de los usuarios. técnicos e industriales de la edificación hacia los procedimientos y sistemas en que se basa los procedimientos y sistemas en que se basa el aprovechamiento de otras fuentes alterna-
tivas de energía, principalmente la solar. Esto tivas de energía, principalmente la solar. Esto comercial que, en opinión de los autores de este libro, arrastran los siguientes defectos: sistemas convencionales que violenta las peculiaridades de la energía solar (baja densidad y variabilidad en el tiempol, y una escasa selectividad en la aplicación de los sistemas y procedimientos pasivos dando origen a un ecumenismo arquitectónico solar, al margen de las condiciones climáticas y funcionales especificas de cada

En este libro, utilizando criterios y metodologia pedagógicos, se dan los fundamentos e instrumentos teórico-prácticos necesarios para el planteamiento de todo proyecto arquitectónico solar pasivo, de acuerdo con los principios éticos y económicos de conservación y ahorro de energia. Es decir: respeto de los presupuestos bioclimáticos, búsqueda de la máxima captación y acumulación de la radiación solar, y esmero en el aislamiento térmico de los cerramientos.

Un volumen encuadernado en cartulina ibiza plastificada, a cinco colores, de $16 \times 23 \mathrm{~cm}$, compuesto de 216 páginas, 217 figuras, 87 gráficos, 19 tablas y 10 cuadros. 